\title{
Kepuasan Pernikahan Berhubungan dengan Kecenderungan Berselingkuh
}

\author{
Vivi Amalia, Yudiana Ratnasari \\ Fakultas Psikologi Universitas Indonesia \\ vivi.muchlis@gmail.com
}

\begin{abstract}
The purpose of this study is to find out the relationship between marital satisfaction and tendency in infidelity among husbands and wives who live in Jabodetabek. The samples of this research are 43 males and 41 females between the ages of 27 and 56 years. The datas were analized using pearson correlation. The results showed that there are a relationship between marital satisfaction and emotional, and emotional physical infidelity. Interpersonal relationship, mutual interest, congruency between role and hope, relationship with in laws, and power and attitudes toward marriage are the domains of marital satisfaction which have a significant relationship with emotional infidelity. The domains mutual interest, relationship with in laws, and power and attitudes toward marriage found have a significant relationship with emostional physical infidelity. Among all those domains, relationship with in laws has more contribution affected tendency in infidelity.
\end{abstract}

Keywords: marriage, marital satisfaction, infidelity

\begin{abstract}
Abstrak. Penelitian ini bertujuan untuk melihat hubungan antara kepuasan pernikahan dengan kecenderungan berselingkuh pada kelompok suami dan istri yang bertempat tinggal di Jabodetabek. Responden penelitian sebanyak 84 orang berusia 27-56 tahun (43 laki-laki, 41 perempuan). Pengambilan data dilakukan dengan menggunakan Inventori Kepuasan Pernikahan dan Kuesioner Infidelity Scale. Adapun pengolahan data dilakukan menggunakan teknik korelasi Pearson. Hasil penelitian menunjukkan bahwa ada hubungan yang signifikan antara kepuasan pernikahan dengan kecenderungan perselingkuhan emosional dan emosional fisik. Domain kepuasan pernikahan yang berkorelasi signifikan dengan kecenderungan perselingkuhan emosional adalah hubungan interpersonal, kesamaan minat, kesesuaian peran dan harapan, hubungan dengan mertua dan ipar, serta kekuasaan dan sikap terhadap pernikahan. Domain kepuasan pernikahan yang berkorelasi signifikan dengan perselingkuhan emosional fisik adalah kesamaan minat, hubungan dengan mertua dan ipar, serta kekuasaan dan sikap terhadap pernikahan. Aspek hubungan dengan mertua dan ipar merupakan aspek yang memiliki kontribusi lebih besar mempengaruhi kecenderungan seseorang untuk berselingkuh.

Kata kunci: pernikahan, kepuasan pernikahan, perselingkuhan
\end{abstract}

Di Indonesia, angka perceraian dari tahun ke tahun semakin meningkat. Dibandingkan dengan negara-negara Islam lainnya, Indonesia berada diperingkat tertinggi tingkat perceraian setiap tahunnya (eramuslim.com, 2007). Data yang tercatat di Dirjen Bimbingan Masyarakat (Bimas) Departemen Agama menunjukkan bahwa pada tahun 2008 angka perceraian meningkat dua kali lipat dari tahun sebelumnya. Ada beragam faktor yang menyebabkan terjadinya perceraian tersebut. Sebagian besar perceraian disebabkan oleh ketidakharmonisan rumah tangga, yaitu sebanyak 46.723 kasus, faktor ekonomi 24.252 kasus, krisis keluarga 4.916 
kasus, cemburu 4.708 kasus, poligami 879 kasus, kawin paksa 1.692 kasus, kawin bawah umur 284 kasus, penganiayaan dan kekerasan dalam rumah tangga (KDRT) 916 kasus, suami atau istri yang menjalani proses hukum yang kemudian pasangannya menikah lagi 153 kasus, cacat biologis sebanyak 581 kasus, perbedaan politik 157 kasus, gangguan dari pihak keluarga 9.071 kasus, dan perselingkuhan 54.138 kasus (kompas.com, 2008). Data tersebut memperlihatkan bahwa cukup banyak perceraian yang disebabkan oleh perselingkuhan. Bahwa perceraian sebagai akibat perselingkuhan jumlahnya mencapai sekitar 36 persen kasus. Itu artinya, cukup banyak pasangan yang mengaku bahwa dirinya berselingkuh dan kemudian bercerai.

Banyak penelitian dan survei memaparkan bahwa kasus perselingkuhan dari tahun ke tahun semakin meningkat. Hasil penelitian Whisman dan Snyder (2007) memperlihatkan bahwa sekitar 2040\% laki-laki dan $20-25 \%$ perempuan yang menikah berselingkuh (Madathil \& Sandhu, 2008). Dalam hitungan kasar, sekitar 50 persen orang yang menikah terlibat dalam berbagai bentuk perilaku selingkuh pada usia tertentu pernikahannya (Drigotas, Safstrom, \& Gentilia, 1999). Laki-laki diperkirakan lebih banyak melakukan perselingkuhan dengan jumlah pasangan selingkuh yang juga lebih banyak dibandingkan dengan perempuan (Lawson, 1988 dalam Buss \& Shackelford, 1997).

Munculnya perselingkuhan dalam ikatan pernikahan disebabkan oleh bermacam-macam hal. Drigotas, Safstrom, dan Gentilia (1999), berdasarkan berbagai literatur menyimpulkan bahwa alasan seseorang berselingkuh, yaitu karena masalah seksual (Glass \& Wright, 1977; 1992), kepuasan emosional di mana salah satunya kepuasan dalam pernikahan (Rini, 2001), konteks sosial, sikap dan norma terhadap hubungan seksual, serta balas dendam karena pasangan juga berselingkuh. Sementara itu, Glass dan Wright (1977) menemukan bahwa perselingkuhan merupakan hal umum dilakukan oleh laki-laki yang sejak awal pernikahan sudah tidak puas dengan pernikahannya. Sementara itu, pada perempuan, perselingkughan sering terjadi karena merka merasa tidak puas ketika menjalani pernikahannya. Perselingkuhan seksual secara positif berasosiasi dengan ketidakbahagiaan dalam pernikahan, kepuasan emosional terhadap pasangan yang rendah, ketidakseimbangan dalam rumah tangga pada perempuan, dan ketidakpuasan dalam hubungan seksual pada laki-laki (Ponzeti, 2003).

Di sisi lain, beberapa penelitian justru melihat bahwa ketidakpuasan dalam pernikahan tidak berkontribusi bagi terjadinya perselingkuhan. Sebuah penelitian yang dilakukan pada responden berkulit putih menemukan bahwa tidak ada hubungan antara perselingkuhan seksual dengan kebahagiaan pernikahan, kualitas hubungan seks atau kepuasan seks secara fisik (Ponzeti, 2003). Sementara itu, Psikolog Glass selama melakukan praktek (1991-2000) menemukan bahwa lebih dari setengah laki-laki dan sepertiga perempuan yang berselingkuh mengaku merasa bahagia dengan pasangan pernikahannya (Williams, Sawyer, \& Wahlstrom, 2006).

Terlepas dari pro dan kontra tentang hubungan ketidakpuasan pernikahan dengan perselingkuhan, kita dapat melihat bahwa ketidakpuasan memperbesar kemungkinan terjadinya perselingkuhan seksual (Ponzetti, 2003), dan perselingkuhan merupakan prediktor yang kuat dan konsisten menentukan suatu pernikahan mengalami perceraian (Previti \& Amato, 2004). Sepertiga perceraian terjadi karena salah satu atau kedua pasangan telah melakukan hubungan seksual dengan orang lain (Lloyd, 1995 dalam Williams, Sawyer, \& Wahlstrom, 2006). Perceraian 
pada anak berdampak pada kesejahteraan psikologis yang rendah, kesulitan dalam menyesuaikan diri, rendahnya prestasi akademis, mengalami masalah perilaku seperti agresivitas (Amato dalam ClarkeStewart dan Brentano, 2006). Untuk itu, penelitian ini mencoba menelaah apakah ketidakpuasan dalam pernikahan secara signifikan menyebabkan seseorang berselingkuh, serta faktor-faktor dalam kepuasan pernikahan yang memiliki pengaruh lebih kuat mendorong terjadinya perselingkuhan.

Kepuasan terhadap pernikahan adalah faktor kedua yang terpenting bagi seseorang setelah faktor usia (Papalia, 2001). Fitzpatrick (1988), menyatakan bahwa banyak istilah yang digunakan untuk mengidentifikasi kepuasan dalam pernikahan, seperti kebahagiaan pernikahan, kualitas pernikahan, dan penyesuaian pernikahan. Kepuasan pernikahan merupakan gambaran subjektif pasangan saat mengevaluasi kualitas dari pernikahannya. Evaluasinya berkaitan dengan seberapa baik, bahagia, dan memuaskan hubungan pernikahan yang mereka jalani (Bird \& Melville, 1994). Penilaian kepuasan pernikahan merupakan pengalaman subjektif perasaan dan sikap yang didasari oleh faktor intraindividual yang mempengaruhi persepsi seseorang terhadap kualitas pernikahannya (Weiss, dalam Pinsof \& Lebow, 2005). Dengan kata lain, kepuasan pernikahan merupakan penilaian subjektif individu terhadap pernikahannya yang dipengaruhi oleh faktor internal dan eksternal individu itu sendiri.

Penelitian-penelitian tentang kepuasan pernikahan menyimpulkan ada faktor-faktor yang berperan sebelum pernikahan dan pada saat pernikahan itu dijalani. Duvall \& Miller, (1985) menegaskan bahwa faktor-faktor kepuasan pernikahan yang penting untuk diperhatikan adalah pada saat menjalani pernikahan dibandingkan sebelum pernikahan berlangsung. Hal ini dikarenakan faktor masa lalu yang merupakan faktor yang tidak dapat diubah lagi dan pasangan mau tidak mau harus menoleransi kondisi tersebut.

Ada beberapa faktor yang dianggap memiliki peran mempengaruhi kepuasan pernikahan seseorang. Faktor yang pertama adalah hubungan interpersonal. Pasangan yang puas dengan pernikahannya memperlihatkan adanya pengalaman bersama yang menyenangkan dan saling mengasihi (Marano 1992 dalam Duffy \& Atwater, 2005). Kepuasan pernikahan akan tercapai jika dalam pernikahan terdapat kedekatan dan adanya kemampuan mengekspresikan rasa saling menghargai dan menyayangi antara kedua pasangan.

Keberadaan anak juga turut mempengaruhi kepuasan pernikahan. Pasangan yang menyatakan dirinya puas dan bahagia dalam pernikahan pada umumnya adalah pasangan yang memiliki anak (Baruch, Barrent \& River dalam Duvall \& Miller, 1985). Namun di sisi lain, kehadiran anak juga dapat menurunkan kepuasan pernikahan Pasangan baru akan mengalami penurunan kepuasan pernikahan saat menjadi orang tua (Duvall \& Miller, 1985).

Hal lain yang sering menentukan kepuasan pernikahan adalah kehidupan seksual. Hubungan seksual yang memuaskan merupakan salah satu karakteristik pernikahan yang bahagia (Schwartz, 2002, dalam Duffy \& Atwater, 2005). Morokoff dan Gillilland, (1993) menemukan bahwa kepuasan pernikahan berkaitan dengan beberapa fungsi dari aspek seksual, seperti kepuasan seksual, persepsi pasangan tentang kepuasan seksual, dan frekuensi melakukan hubungan seksual (Perl, 2008). Donnelly (1993) menyatakan bahwa pasangan yang tidak melakukan hubungan seksual lagi 
menjadi indikator bahwa adanya masalahmasalah lain dalam pernikahan (Perl, 2008).

Komunikasi juga memegang peranan penting dalam menentukan kepuasan pernikahan, karena komunikasi menjembatani masing-masing pasangan sehhingga mampu mengemukakan saling pengertian, perasaan nyaman, cinta, simpati, setia, dan sesuai dengan kebutuhannya (Duvall \& Miller, 1985). Kualitas komunikasi antara kedua pasangan merupakan hal penting karena kemampuan komunikasi mempengaruhi bagaimana pasangan mengatasi perbedaan dan masalah yang dihadapi dalam pernikahan (Marano, 1992 dalam Duffy \& Atwater, 2005).

Kesamaan minat juga turut mempengaruhi kepuasan pernikahan seseorang. Penelitian menunjukkan bahwa pasangan suami istri yang merasa bahagia dengan pernikahannya lebih sering melakukan aktivitas bersama seperti rekreasi atau pun kegiatan lain di luar rumah (Duvall \& Miller, 1985).

Kesesuaian peran dan harapan berperan penting bagi kepuasan pernikahan. Duvall dan Miller, (1985) menjelaskan bahwa peran seseorang dalam pernikahan adalah sejumlah harapan dalam masyarakat tertentu tentang tingkah laku yang harus ditampilkan oleh suami atau istri. Pasangan yang tidak puas dengan pembagian tugas dalam rumah tangga akan menjadi kurang puas dengan pernikahannya (Suitor, 1991). Ellen Efron Pimentel (2000) mempelajari tentang hubungan pernikahan di Cina, menemukan pasangan merasa sangat bahagia ketika sama-sama mereka memiliki pandangan yang egaliter dan berbagi ketika membuat suatu keputusan. Istri merasa lebih bahagia dibandingkan dengan suami ketika pekerjaan rumah tangga juga dikerjakan juga oleh suami (Seccombe \& Warner, 2004).
Partisipasi keagamaan dapat membawa pada kehidupan pernikahan yang memuaskan, kenyamanan bagi individu dan mampu membangun ikatan antar sesama anggota keluarga, tapi juga bisa menjadi pemicu masalah pada pasangan (Patterson, dkk, 2000). Bagi beberapa pasangan, masalah yang berkaitan dengan agama bisa menjadi pemicu argumentasi yang panjang dan menimbulkan kemarahan (Olson \& DeFrain, 2006).

Masalah keuangan merupakan hal yang penting dalam usaha mencapai kepuasan pernikahan. Faktor ini merupakan salah satu area konflik yang sering terjadi dalam suatu pernikahan. Banyak keluarga yang mengalami masalah keuangan pada setiap tahap siklus perkembangan keluarga. Penelitian Olson dan Olson (2000), terhadap 5.153 pasangan suami istri yang bahagia dan 5.127 pasangan yang tidak bahagia, masalah pengaturan keuangan merupakan hal yang membedakan antara kedua kelompok tersebut dalam hal bagaimana membelanjakan uang mereka, kekhawatiran dalam pengaturan keuangan keluarga, keputusan dalam menabung, masalah hutang, serta kesulitan dalam memutuskan pengeluaran keuangan keluarga (Olson \& DeFrain, 2006).

Hal lain yang mempengaruhi kepuasan pernikahan adalah hubungan pasangan dengan mertua dan ipar. Hubungan yang baik dengan keluarga pasangan merupakan ciri pernikahan yang bahagia (Zastrow \& Kirst-Ashman, 2001). Penelitian Pimentel (2000) tentang kualitas pernikahan di Cina, menemukan bahwa persetujuan orang tua terhadap pasangan yang dinikahi memiliki pengaruh kepuasan pernikahan. Persetujuan ini mempengaruhi bagaimana interaksi pasangan dengan mertua dan iparnya setelah menjalani pernikahan (Seccombe dan Warner, 2004). Indonesia juga memiliki kemiripan dengan Cina, di 
mana seseorang tidak bisa dilepaskan dari keluarga besarnya.

Pasangan yang menikah akan mencapai kepuasan juga tergantung pada kemampuan mereka menghadapi konflik. Salah satu karakteristik pernikahan yang memuaskan adalah adanya kemampuan memecahkan masalah bersama. Faktor ini disebutkan lebih dari dua per tiga pasangan yang memiliki tingkat kepuasan pernikahan yang tinggi sedangkan pasangan yang tidak puas dengan pernikahannya jarang menyebutkan faktor ini (Marano, 1992 dalam Duffy \& Atwater, 2005).

Kekuasaan dan sikap dalam pernikahan menjadi lain penentu kepuasan pernikahan. Kekuasaan dalam pernikahan ditandai dengan adanya individu yang menguasai, mengontrol pasangannya, dan memiliki hak untuk membuat keputusan yang mempengaruhi kehidupan mereka. Dalam pernikahan tradisional, suami memiliki kekuasaan yang lebih besar. Namun, juga ada perempuan yang superior yang membuat banyak keputusan dalam pernikahannya. Pasangan yang berpendidikan, sikap yang egaliter merupakan sikap yang lebih diterima, di mana tidak ada pasangan yang lebih dominan sehingga semua keputusan dalam pernikahan bisa diputuskan bersama-sama. Olson dan Olson, (2000) berdasarkan hasil surveinya memperoleh bahwa pasangan mempersepsi bahwa hubungan mereka egaliter cenderung memiliki tingkat kepuasan pernikahan yang tinggi (Olson \& DeFrain, 2006).

Hal lain yang memiliki keterkaitan dengan kepuasan pernikahan adalah kepuasan perselingkuhan. Perselingkuhan dijelaskan dalam banyak istilah dalam bahasa Inggris, seperti cheating, having an affair, stepping out, being unfaithful, extradyadic sexual involvement infidelity, extramarital sexual, dan adultery. Perselingkuhan merupakan ketidaksetiaan dalam pernikahan pada level kedekatan emosi dan fisik (Drigotas dan Barta, 2001) yang kadang diikuti oleh perilaku berhubungan seksual dengan orang lain di luar ikatan pernikahan atau hubungan yang sedang dijalankan (Williams, Sawyer, \& Wahlstrom, 2006; McAnulty \& Brineman, 2007).

Kita dapat melihat hubungan ketidakpuasan pernikahan dengan kecenderungan perselingkuhan berdasarkan beberapa penelitian menurut tingkat kualitas hubungan dalam pernikahan. Glass (dalam Buss \& Shackelford, 1997) menemukan bahwa perselingkuhan dilakukan oleh laki-laki yang sejak awal menikah tidak puas pada pernikahannya. Laki-laki yang memiliki kebutuhan hubungan seksual yang tinggi, memiliki nilai permisif tentang hubungan seksual, serta ketidakpuasan terhadap pernikahan yang sedang dijalaninya namun tidak terlalu berani untuk bercerai cenderung mencari orang lain untuk memenuhi kebutuhan tersebut (Sawyer, \& Wahlstrom, 2006). Atkins (dalam Peluso, 2006) menemukan bahwa orang yang berselingkuh memiliki latar belakang pernikahan yang tidak stabil, bertengkar tentang isu kepercayaan, dan narsis, dan sedikit menghabiskan waktu bersama pasangannya. Wright (dalam Buss \& Shackelford, 1997) memaparkan bukti-bukti bahwa ketidakpuasan seksual dalam pernikahan berasosiasi dengan peningkatan kecenderungan laki-laki untuk berselingkuh. Kecenderungan untuk mudah berselingkuh seksual pada laki-laki semakin tinggi karena laki-laki melihat perselingkuhan seksual sebagai justifikasi dan menambah pengalaman dengan sedikit rasa bersalah dalam melakukannya (Johnson; Athanasiou et al.; Spanier \& Margolis; dalam Buss \& Shackelford, 1997). 
Berdasarkan penelitian-penelitian tentang laki-laki yang berselingkuh di atas, jika dikaitkan dengan tiga faktor yang membentuk intensi, kita dapat memberikan jabaran seperti berikut. Dari sisi sikap terhadap perilaku selingkuh, terlihat bahwa laki-laki yang memiliki sikap positif terhadap perilaku selingkuh ketika melakukannya karena ingin mendapatkan pengalaman dan hanya sedikit merasa bersalah terhadap perilakunya itu, serta memiliki nilai permisif terhadap perilaku seksual diketahui memiliki kemungkinan besar untuk berselingkuh. Faktor norma subjektif yang dimiliki individu bahwa perceraian merupakan hal yang dihindari dalam norma sosialnya sehingga tidak berani untuk melakukannya, maka kemungkinan besar memilih untuk berselingkuh ketika mengalami ketidakpuasan dalam pernikahan. Faktor ketiga yang membentuk intensi berupa kontrol terhadap perilaku yang cenderung akan dilakukan. Laki-laki yang mengalami masalah-masalah yang berkaitan dengan ketidakpuasan akan pernikahan, hubungan seksual yang tidak memuaskan mendorong keinginannya untuk mencari orang lain yang dapat memberikan kepuasan yang diharapkan karena laki-laki memiliki kecenderungan untuk melakukan perselingkuhan seksual karena merasa tidak puas dengan pasangannya. Jika ketiga komponen ini dimiliki seseorang yaitu sikap yang positif terhadap perilaku selingkuh dan tidak berani melakukan perceraian, dan memiliki keinginan untuk mendapatkan kepuasan dari orang lain selain pasangannya diperkirakan semakin besar kemungkinan intensi untuk berselingkuh dapat menjadi perilaku yang nyata. Terlebih lagi, jika intensi tersebut mendapatkan waktu dan kesempatan yang tepat untuk melakukannya, seperti adanya jarak fisik antara kedua pasangan (Drigotas, Safstrom, \& Gentilia, 1999) maka semakin besar kecenderungan berselingkuh akan diperlihatkan dalam perilaku berselingkuh.

Pada perempuan, perselingkuhan dapat terjadi ketika ia merasa tidak puas akan pernikahannya selama menjalani pernikahan itu (Glass, 1997 dalam Buss \& Shackelford, 1997). Menurut Peterson (1983) perempuan yang tidak puas dalam hubungan seksual pernikahannya cenderung untuk berselingkuh dan dalam hubungan perselingkuhannya perempuan lebih sering melibatkan emosi (Glass \& Wright, 1985 dalam Buss \& Shackelford, 1997). Sama dengan laki-laki, perempuan yang memiliki kebutuhan hubungan seksual yang tinggi, memiliki nilai permisif tentang hubungan seksual di luar pernikahan, serta ketidakpuasan terhadap pernikahan yang sedang dijalaninya namun tidak terlalu berani untuk bercerai cenderung mencari orang lain untuk memenuhi kebutuhan tersebut (Treas dan Giesen 2000 dalam Williams, Sawyer, dan Wahlstrom, 2006). Berdasarkan penelitian tersebut, dapat dijelaskan bahwa kecenderungan berselingkuh menjadi lebih kuat jika perempuan tersebut memiliki sikap positif terhadap perilaku selingkuh, karena memiliki nilai permisif terhadap perilaku seksual di luar nikah, serta memiliki norma bahwa lebih baik berselingkuh dari pada bercerai dari pasangan sahnya. Kecenderungan berselingkuh semakin besar dengan adanya ketidakpuasan emosional yang membuat perempuan cenderung mencari pemuasan dengan orang lain dalam bentuk kedekatan emosional. Jika ketiga komponen yang membentuk kecenderungan berselingkuh ini ada seorang perempuan maka semakin besar kecenderungan itu menjadi perilaku selingkuh. Faktor lain yang mendukung jika perempuan tersebut kesempatan untuk melakukannya, seperti saat bekerja (Satiadarma, 2001) maka intensi untuk berselingkuh lebih besar kemungkinannya menjadi perilaku nyata berselingkuh. 


\section{Metode}

Penelitian ini menggunakan pendekatan kuantitatif. Pendekatan pengambilan sampel dalam penelitian ini adalah non random sampling, dengan teknik incidental sampling. Kriteria responden adalah perempuan atau laki-laki yang memiliki usia pernikahan minimal 4 tahun, bekerja, pendidikan minimal D3, dan berdomisili di Jabodetabek. Dalam studi ini digunakan dua alat ukur, yaitu Inventori Kepuasan Pernikahan yang disusun oleh Herfianti (2005) dan kuesioner Infidelity Scale yang disusun oleh Drigotas (1999).

Inventori Kepuasan Pernikahan terdiri atas 11 domain, yaitu hubungan interpersonal, anak, kehidupan seksual, komunikasi, kesamaan minat, kesesuaian peran dan harapan, partisipasi keagamaan, keuangan, hubungan dengan mertua dan ipar, kemampuan menghadapi konflik, kekuasaan dan sikap terhadap pernikahan. Inventori ini berbentuk skala likert dengan range nilai 0-3 dengan pilihan jawaban dari tidak pernah, kadang-kadang, sering, dan selalu. Uji validitas konstruk alat ukur menunjukkan bahwa ada 62 item yang memiliki internal konsistensi yang baik dengan koefisien alpha sebesar $\alpha=0,944$.

Infidelity Scale (IS) dapat melihat tiga kecenderungan perselingkuhan, yaitu perselingkuhan emosional, fisik, dan emosional fisik. Pertanyaan pada IS dimulai dengan menanyakan perasaan dan perilaku yang mungkin atau tidak mungkin dianggap sebagai ketidaksetiaan, dan kemudian pertanyaan mulai mengkonfrontasi perasaan atau perilaku tersebut. Responden diminta untuk menilai setiap perasaan dan perilaku yang ditanyakan pada range 0-8 skala Likert. Angka 0 mengindikasikan bahwa tidak ada perasaan atau perilaku tidak setia. Angka 8 mengindikasi perasaan dan perilaku tidak setia yang sangat tinggi. Skor total dari IS dengan skala likert dari 0-9 adalah 82. Uji validitas menunjukkan bahwa 11 item IS memiliki internal konsistensi yang tinggi dengan skor total dengan besaran reliabilitas dengan menggunakan alpha cronbach, yaitu sebesar $\alpha=0,95$.

\section{Hasil}

Responden penelitian sebanyak 84 orang yang terdiri atas 43 laki-laki dan 41 perempuan yang berusia 27-56 tahun. Responden hampir keseluruhannya beragama Islam. Hanya satu responden perempuan yang beragama Katolik. Responden kebanyakan memiliki latar belakang budaya dari suku Jawa, baik itu responden laki-laki (46,5\%) maupun perempuan $(43,9 \%)$. Untuk pasangan responden, kebanyakan juga berasal dari suku Jawa. Responden laki-laki sebanyak $39,5 \%$ dan perempuan sebanyak $65 \%$. Latar belakang pendidikan responden laki-laki dan perempuan mayoritas S1 dengan masing-masing persentase $55,8 \%$ dan 53,7\%. Kedua kelompok responden lebih banyak memiliki pekerjaan sebagai pegawai negeri sipil, yaitu 53,5\% untuk laki-laki dan $43,9 \%$ untuk perempuan. Dilihat dari lama ikatan pernikahan yang sudah dijalani, responden laki-laki dan perempuan lebih banyak telah menjalani pernikahan 4-10 tahun, yaitu 79,2\% dan $73,2 \%$.

Gambaran tingkat kepuasan pernikahan (KP) didapatkan bahwa lakilaki banyak yang merasa puas dengan pernikahannya pada tingkat yang tinggi $(\mathrm{N}=22)$, begitu juga pada perempuan $(\mathrm{N}=17)$. Untuk kecenderungan berselingkuh diketahui bahwa laki-laki lebih banyak memiliki kecenderungan perselingkuhan emosional $(\mathrm{N}=28)$, fisik $(\mathrm{N}=32)$, dan emosional fisik $\mathrm{N}=(34)$ pada level yang rendah. Ini menunjukkan bahwa laki-laki memiliki kecenderungan yang rendah untuk berselingkuh. 
Tabel 1.

Hubungan antara kepuasan pernikahan dengan kecenderungan berselingkuh

\begin{tabular}{lcccc}
\hline & & PE & PF & PEF \\
\hline KP & Korelasi & $-0,267^{*}$ & $-0,195$ & $-0,238^{*}$ \\
& $\mathrm{~N}$ & 79 & 79 & 79 \\
\hline
\end{tabular}

Pada perempuan, diperoleh hasil yang sama, yaitu kecenderungan perselingkuhan emosional $(\mathrm{N}=28)$, fisik $(\mathrm{N}=32)$, dan emosional fisik $(\mathrm{N}=33)$ pada level yang rendah. Ini menunjukkan bahwa perempuan memiliki kecenderungan yang rendah untuk berselingkuh.

Hasil korelasi pada tabel 1. memperlihatkan bahwa ada korelasi yang signifikan antara kepuasan pernikahan (KP) dengan kecenderungan perselingkuhan emosi (PE) dan perselingkuhan emosional fisik. Namun, tidak ada korelasi yang menunjukkan bahwa $\mathrm{R}^{2}=0,059, \mathrm{~F}=5,92$, signifikansi 0,017. Ini berarti 6 persen dari variabilitas dalam perselingkuhan emosi (KE) dapat dijelaskan oleh tingkat kepuasan dalam pernikahan (KP). Pada perselingkuhan emosional fisik (PEF), hasil regresi memperlihatkan $\mathrm{R}^{2}=0,044, \mathrm{~F}=$ 4,603, signifikansi 0,035. Ini memperlihatkan bahwa 4 persen dari variabilitas dalam perselingkuhan emosional fisik (PEF) dapat dijelaskan oleh tingkat kepuasan dalam pernikahan. Kedua hasil regresi menjelaskan bahwa kepuasan

Tabel 2

Faktor-faktor kepuasan pernikahan yang berkorelasi signifikan dengan perselingkuhan emosional

\begin{tabular}{lcc|ccc}
\hline \multicolumn{1}{l}{ HI } & KM & KMH & HDMI & KPSTP \\
\hline PE & & & & & \\
\hline Pearson & $-0,251^{*}$ & $-0,283^{* *}$ & $-0,222^{*}$ & $-0,340^{* *}$ & $-0,246^{*}$ \\
\hline $\mathrm{N}$ & 84 & 84 & 84 & 83 & 84 \\
\hline
\end{tabular}

signifikan antara kepuasan pernikahan (KP) dengan kecenderungan perselingkuhan fisik (KPF). Ini berarti ada hubungan yang signifikan antara kepuasan pernikahan (KP) dengan kecenderungan perselingkuhan emosional (PE) dan perselingkuhan emosional fisik (PEF) akan tetapi tidak ada hubungan yang signifikan antara kepuasan pernikahan dengan kecenderungan perselingkuhan fisik (KPF).

Pada Tabel 3 dijelaskan tentang hasil regresi Inventori Kepuasan Pernikahan (KP) dengan kecenderungan perselingkuhan emosional (KPE) pernikahan (KP) mempunyai pengaruh terhadap kecenderungan perselingkuhan emosional (PE) dan perselingkuhan emosional fisik (PEF) namun pengaruhnya tidak terlalu besar.

Hasil regresi pengaruh faktor kepuasan pernikahan (KP) dengan kecenderungan selingkuh emosional (PE) memperlihatkan bahwa hanya faktor hubungan dengan mertua dan ipar (HMI) dianggap sebagai variabel yang paling banyak pengaruhnya paling besar $R^{2}=$ 0,104, $\mathrm{F}=10,569$ dan signifikansi pada 0,02. Ini berarti ada 10 persen variabilitas dalam 
perselingkuhan emosional (PE) yang dapat dijelaskan oleh tingkat kepuasan hubungan dengan mertua dan ipar (HMI). Ini juga memperlihatkan bahwa ada 90 persen mempengaruhi terjadinya perselingkuhan emosi dan emosional fisik dalam pernikahan.

Hasil tersebut memperkuat pendapat

Tabel 3.

Faktor-faktor kepuasan pernikahan yang berkorelasi signifikan dengan perselingkuhan emosional fisik

\begin{tabular}{rccc}
\hline & KM & HDMI & KPSTP \\
\hline PEF & $-0,237^{*}$ & $-0,344^{* *}$ & $-0,220^{*}$ \\
$\mathrm{~N}$ & 84 & 83 & 84 \\
\hline
\end{tabular}

**. Correlation is significant at the 0.01 level (2-tailed).

varians lain yang mempengaruhi perselingkuhan emosional (PE) yang tidak bisa dijelaskan oleh variabel hubungan dengan mertua dan ipar (HMI).

Hasil regresi faktor-faktor kepuasan pernikahan (KP) yang berkorelasi signifikan dengan kecenderungan perselingkuhan emosional fisik (PEF) menunjukkan $\mathrm{R}^{2}=$ $0,107, \mathrm{~F}=10,874$ dan signifikansi pada 0,01 . Ini berarti ada 11 persen variabilitas dalam perselingkuhan emosional fisik (PEF) yang dapat dijelaskan oleh tingkat kepuasan hubungan dengan mertua dan ipar (HMI). Ini juga memperlihatkan bahwa ada 89 persen varians lain yang mempengaruhi perselingkuhan emosional fisik (PEF) yang tidak bisa dijelaskan oleh variabel hubungan dengan mertua dan ipar (HMI).

\section{Diskusi}

Hasil dari penelitian ini menunjukkan bahwa ada hubungan yang signifikan antara kepuasan pernikahan dengan kecenderungan perselingkuhan emosional dan emosional fisik. Hal itu dapat diartikan bahwa penurunan tingkat kepuasan pernikahan akan diikuti dengan naiknya kecenderungan perselingkuhan emosional dan emosional fisik. Seseorang yang tidak puas dengan pernikahannya diperkirakan mempunyai kecenderungan untuk melakukan perselingkuhan emosional dan emosional fisik. Namun, kontribusi kepuasan pernikahan sangat sedikit
Buss dan Shackelford (1997) bahwa tingkat kepuasan pernikahan merupakan salah satu alasan seseorang berselingkuh. Menurut Drigotas (dalam Safstrom, Gentilia, 1999) bahwa seseorang yang cenderung melakukan perselingkuhan emosional fisik diperkirakan memiliki hubungan yang dekat secara emosi, kognitif, dan fisik dengan orang lain selain pasangannya. Ini berarti bahwa seseorang yang tidak puas dengan pernikahannya akan memiliki kecenderungan untuk dekat secara emosional yang kemudian mungkin diikuti dengan kedekatan fisik.

Kepuasan pernikahan tidak memiliki hubungan yang signifikan dengan kecenderungan perselingkuhan fisik. Penelitian pada responden kulit putih diketahui bahwa tidak ada hubungan antara perselingkuhan seksual dengan kebahagiaan pernikahan, kualitas hubungan seks atau kepuasan seks secara fisik (Ponzeti, 2003). Sejalan dengan penelitian yang dilakukan oleh Psikolog Glass selama melakukan praktek (19912000) menemukan bahwa perselingkuhan dapat terjadi dalam pernikahan yang suami dan istri masih saling mencintai. Semua pasangan yang ditanganinya, lebih dari setengah laki-laki dan satu per tiga perempuan yang berselingkuh mengaku merasa bahagia dengan pasangan pernikahannya (dalam Williams, Sawyer, dan Wahlstrom, 2006). 
Faktor lain yang mungkin berpengaruh dalam hasil penelitian ini adalah latar belakang responden yang berasal dari budaya Jawa dan agama Islam. Norma yang dimiliki seseorang mempengaruhi bagaimana mereka bersikap terhadap perilaku berselingkuh (Drigotas, Safstrom, dan Gentilia, 1999). Norma dan nilai dalam budaya Jawa dan agama Islam dengan tegas melarang perilaku-perilaku yang mengarah pada perselingkuhan fisik, seperti berciuman, membelai dengan lembut, bercumbu, seks oral, atau hubungan seks (Drigotas \& Barta dalam Mazza, 2009).

Dilihat dari semua faktor-faktor yang memiliki hubungan signifikan dengan kepuasan pernikahan, dapat dikatakan bahwa pasangan suami istri yang memiliki pendidikan tinggi, berkarir, dan tinggal di wilayah perkotaan melihat faktor berikut ini sangat penting dalam mempengaruhi terjadinya perselingkuhan emosional dan emosional fisik, yaitu hubungan interpersonal, kesamaan minat, kesesuaian peran dan harapan, hubungan dengan mertua dan ipar, dan kekuasaan dan sikap terhadap pernikahan. Dalam aspek kesesuaian peran dan harapan, Duvall dan Miller, 1985 menyatakan pada pasangan yang berpendidikan, sikap yang egaliter merupakan sikap yang lebih diterima, di mana tidak ada pasangan yang lebih dominan sehingga semua keputusan dalam pernikahan bisa diputuskan bersama-sama.

Namun, di antara faktor-faktor di atas, faktor hubungan dengan mertua dan ipar memiliki pengaruh yang paling besar mempengaruhi seseorang untuk melakukan perselingkuhan emosional dan emosional fisik. Meskipun besaran pengaruh antara kedua variabel ini tidak terlalu besar (sekitar $10 \%$ ). Temuan ini memberikan bukti bahwa masalah-masalah dalam pernikahan yang berkaitan dengan hubungan mertua dan ipar menurunkan kepuasan pernikahan dan mendorong seseorang untuk berselingkuh.

Dilihat dari latar belakang budaya di masyarakat Indonesia, kita mengetahui bahwa orang tua dan keluarga besar memiliki pengaruh terhadap bagaimana suatu pernikahan terjadi dan berjalan. Hubungan yang tidak baik dengan keluarga pasangan mempengaruhi bagaimana seseorang berinteraksi dengan keluarga pasangannya dan interaksi ini mempengaruhi kepuasan pernikahan (Primentel, 2000 dalam Seccombe dan Warner, 2004). Ini berarti jika seseorang tidak dapat menyesuaikan diri dengan keluarga pasangannya akan menimbulkan suatu masalah yang menurunkan kepuasan pernikahan. Untuk itu, pasangan yang mengalami masalah dalam membina hubungan baik dengan keluarga besar pasangannya sebaiknya berusaha mencari solusi yang terbaik untuk dirinya dan keluarga pasangannya agar tidak menyebabkan terjadinya ketidakpuasan dalam pernikahan.

Hasil tambahan dari penelitian ini memperlihatkan secara umum tingkat kecenderungan perselingkuhan responden berada pada tingkat rendah. Ini dapat berarti bahwa responden benar-benar memiliki kecenderungan yang rendah untuk berselingkuh atau mereka melakukan faking good. Perselingkuhan merupakan perilaku yang ditutup-tutupi atau rahasia yang sulit diceritakan oleh seseorang kepada orang lain dengan jujur dan terbuka (Drigotas, Safstrom, dan Gentilia, 1999) sehingga tidak menutup kemungkinan responden penelitian ini melakukan faking good dalam menjawab pertanyaan yang berkaitan dengan perselingkuhan.

Hal lain yang diperoleh dalam penelitian ini adalah tidak ada perbedaan yang signifikan dalam tingkat kepuasan pernikahan antara responden laki-laki dan perempuan. Ini menunjukkan bahwa 
tingkat kepuasan pernikahan kelompok laki-laki dan perempuan yang berkarir tingkat pendidikan yang tinggi, dan tinggal di daerah perkotaan cenderung sama, baik itu tingkat kepuasan pernikahan. Ini menunjukkan bahwa tidak ada perbedaan jender dalam tingkat kepuasan pernikahan, serta pada pada laki-laki dan perempuan tingkat kepuasan pernikahan mengalami penurunan setiap tahunnya pada level yang sama (Olson \& DeFrain, 2006).

Untuk

kecenderungan perselingkuhan, diketahui bahwa tidak ada perbedaan jender dalam tingkat kecenderungan berselingkuh emosional, fisik, dan emosional fisik. Seseorang yang memiliki pendidikan yang tinggi cenderung untuk lebih toleran terhadap perilaku selingkuh (Ponzetti, 2003). Ini mengindikasikan bahwa perempuan dan laki-laki yang memiliki pendidikan tinggi memiliki pandangan yang sama terhadap perselingkuhan. Hasil ini berbeda dengan kajian Buss dan Shackelford (1997) pada beberapa penelitian sebelumnya yang menemukan bahwa laki-laki lebih cenderung berselingkuh tanpa melibatkan emosi sedangkan pada perempuan lebih banyak melibatkan emosinya.

\section{Kesimpulan dan Saran}

Hasil penelitian ini menunjukkan bahwa faktor kepuasan pernikahan memiliki pengaruh sedikit akan kecenderungan seseorang untuk berselingkuh. Ini mengindikasikan bahwa ada variabel lain yang memiliki peran mendorong seseorang untuk berselingkuh. Hasil penelitian ini memberikan masukan bahwa perselingkuhan fisik tidak dipengaruhi oleh kepuasan pernikahan.

Ini memperlihatkan bahwa ada faktor-faktor lain yang tidak berkaitan dengan kepuasan pernikahan yang memiliki pengaruh besar terhadap kecenderungan seseorang untuk melakukan perselingkuhan fisik.

Untuk peneliti selanjutnya, pengumpulan data, lebih baik dilakukan di rumah daripada di kantor, agar kuesioner langsung dikembalikan. Selain itu, sebaiknya saat pengisian kuesioner pada responden yang berpasangan lebih baik tidak dilakukan saat bersamaan. Peneliti sebaiknya juga memilih sampel yang representatif serta menggali faktor lain penentu kepuasan pernikahan selain perselingkuhan.

Bagi pasangan suami istri yang mengalami masalah dengan pasangannya, sebaiknya segera mengatasi masalah tersebut. Hal itu penting agar ia tidak sampai menurunkan tingkat kepuasan pernikahan dan mendorong terjadinya perselingkuhan.

\section{Kepustakaan}

Eramuslimnews. (2007, 15 Agustus). Angka perceraian di Indonesia tertinggi, dibanding negara Islam lain. Diunduh dari http://www.eramuslim.com/berita/nasio nal/angka-perceraian-di-indonesiatertinggi-dibanding-negara-islamlain.htm).

Kompas. (2008, 15 Juli). Sepuluh persen perkawinan berakhir perceraian. Diunduh darihttp://female.kompas.com/read/xml /2008/07/15/19574987/sepuluh.persen.pe rkawinan.berakhir.perceraian.

Bird, G. \& Melville, K. (1994). Families and Intimate Relationships. London: McGraw Hill, Inc

Buss, D. M., \& Shackelford, T.K. (1997). Susceptibility to infidelity in the first year of marriage. Journal of Research in Personality, 31, 193-221.

Clarke-Stewart, A., \& Brentano, C. (2006). Divorce: Causes and consequences. New Haven and London: Yale University Press. 
Drigotas, Stephen M, \& Barta, William. (2001). The Cheating Heart: Scientific Explorations of Infidelity. Journal Psychological Science. Vol. 10 177-180.

Drigotas, S.M., Safstrom, C.A., \& Gentilia, T. (1999). An investment model prediction of dating infidelity. Journal of Personality and Social Psychology, 77(3) 509-524.

Duffy, K.G., \& Atwater, E. (2005). Psychology for living: Adjusment, growth, and behavior, $8^{\text {th }} E d$. New Jersey : Pearson Prentice Hall.

Duvall, E.M., \& Miller, B. C. (1985). Marriage and Family Development. New York, Harper \& Row

Fitzpatrick, M. A. (1988). Between husbands and wives: Communication in marriage. Newbury Park, CA: Sage.

Glass, S.P \& Wright, T.L. (1977). The Relationship of extramarital sex, length of marriage and sex differences in marital satisfaction and romanticism. Journal of Marriage and Family. 39. 691703.

Glass, S.P \& Wright, T.L. (1992). Justification for extramarital relationships: The association between attitudes, behaviors, and gender. Jornal of Sex Research. 29. 361-387.

Herfianti, Fitri. (2005). Inventori Kepuasan Pernikahan. Depok: Tugas Akhir Profesi Klinis Dewasa Fakultas Psikologi Universitas Indonesia.

Madathil, J. \& Sandhu, D.S. (2008) Infidelity in Asian Indian marriages: Implications for counseling and psychotherapy. The Family Journal. 16, 338. Diunduh dari http://tfj.sagepub.com/cgi/content/abstra ct/16/4/338.

Mazza, T Marisa. (2009). Justification of Infidelity: Self Reported Factors that Lead to Infudelity. San Fransisco: A dissertation: The California School of Professional Psychology.

McAnulty, R.D \& Brineman, M.J. (2007). Infidelity in Dating Relationships.
Journal Annual Review of Sex Research. 18. 94-114.

Papalia, D.E., \& Olds, S.W. (2001). Human Development $8^{\text {th }}$ Edition. New York: McGraw Hill.

Patterson,J., Hayworth, M., Turner, C., \& Raskin, M. (2000). Spiritual Issues in Family Therapy: A graduate level course. Journal of Marital and Family Therapy. 26. 199-210.

Perl, S. (2008). Marital satisfaction. Disseration. Florica: Faculty of The American of Clinical Sexologists Maimonides University.

Peluso, Paul. R. (2006). Infidelity: A Practitioner's Guide to Working with Couples in Crisis. New York: Taylor \& Francis Group, LLC.

Pimentel, E, Effron. (2000). Just How Do I Love Thee?:Marital Relations in Urban Chine. Jurnal of Marriage and Family, 62, 32-47.

Pinsof, W.M., \& Lebow, J. (2005). Family Psychology: The art of the science. New York: Oxford University Press.

Ponzetti, J. (2003). International encyclopedia of marriage and family Volume $12^{\text {nd }} E d$. New York: Macmillan Reference USA.

Olson, D.H., \& DeFrain, J. (2006). Marriages and families: Intimacy, diversity, and strengths. $5^{\text {th }}$ ed. New York: McGraw Hill.

Rini, J.F. (2001). Perselingkuhan untuk memenuhi kebutuhan seksual. Diunduh dari http://www.e-psikologi.com/epsi /search.asp/ pada 29 Agustus 2009.

Satiadarma, M. P. (2001). Menyikapi perselingkuhan. Jakarta: Pustaka Populer Obor.

Seccombe, K., \& Warner, R. L. (2004). Marriages and Families : Relationship in social context. Belmont, CA: Wodsworth/Thompson.

Subtonik, R.B., \& Haris, G. (2005). Surviving Infidelity : Making decisions, recovering from the pain (3rd ed.). Cincinnati, $\mathrm{OH}$ : Adams Media 
Suitor, J.J. (1991). Marital Quality and Satisfaction with the Division of Haousehold Labor across the Family Life Cycle. Journal of Marriage and Family. 53. 221-230.

Williams, Brian, K; Sawyer, Stacey C., Wahlstorm, Carl M. (2006). Marriages, Families, and Intimate Relationships: A Practical Introduction. Boston: Pearson Education Inc.
Zastrow, C., \& Kirst-Ashman, K. (2001). Understanding human behavior and the social environment. Chichago: Nelson Hall 